\title{
Factors Affecting Equity and Its Impact on Insurance Premium of General Insurance Companies in Indonesia
}

\author{
M. Noor Salim \\ University of Mercu Buana, Indonesia \\ E-mail:m_noorsalim@yahoo.com \\ Sukarman \\ PT. Asuransi Mega Pratama \\ E-mail: sukarman.akmaliah@gmail.com
}

Received: Nov. 21, 2018

Accepted: Dec. 11, 2018 Published: Dec. 21, 2018

doi:10.5296/ifb.v5i2.14092

URL: http://dx.doi.org/10.5296/ifb.v5i2.14092

\begin{abstract}
The phenomenon that was appointed to be the object of research was the decline in the percentage of premium income in general insurance companies in Indonesia while the equity value (capitalization) of the company increased. This study aims to determine the effect that occurs due to the influence of the variables of free working capital, investment, assets and equity on the acquisition of premiums. The research data is secondary data taken from the OJK website. Processing data using multiple linear regression methods, and using two sub-structure equation techniques because in this study using intervening variables. From the results of the study conclusions are as follows: Working capital does not have a significant positive effect on equity, investment has a significant positive effect on equity, assets do not have a significant effect on equity, working capital does not significantly influence the acquisition of premiums, investment does not significantly influence the acquisition of premiums, assets no significant effect on the acquisition of premiums, equity has a positive and significant effect on the acquisition of premiums. In this study, equity mediates the effect of working capital, investment, assets on the acquisition of premiums.
\end{abstract}

Keywords: premiums, equity, working capital, investment, assets 


\section{Introduction}

The map of the condition of the Indonesian insurance sector towards the ASEAN Economic Community has begun in 2016, and it has been predicted that Indonesia has the potential to become a big market for the development of the insurance industry in Southeast Asia. With the largest population in Southeast Asia and the rapidly growing middle class (predicted to reach 74 million by the end of 2016 (www.news.analisadaily.com, accessed September 25, 2017 ) insurance use is still low where only $11.81 \%$ of Indonesia's population who have access to insurance from a total of $88.19 \%$ (OJK, 2016). Looking at existing data, Indonesia is a very potential country given the largest population, the widest area and low penetration and density. Therefore, the need to push the industry national insurance in order to be able to expand to foreign markets, encourage the national insurance industry to be more competitive, increase capacity and optimize the use of domestic capacity, encourage insurance providers to be healthier, fairer, trustworthy and reliable, and encourage the process of equality of recognition among fellow countries member.

The prospect of the insurance industry can also be seen from the value of equity that continues to increase every year in this industry. In the OJK report, the equity value of this sector experienced a rate of increase. This will bring a positive trend for the domestic insurance industry to prepare for the ASEAN Economic Community (MEA) event where the insurance industry sector will be strengthened.

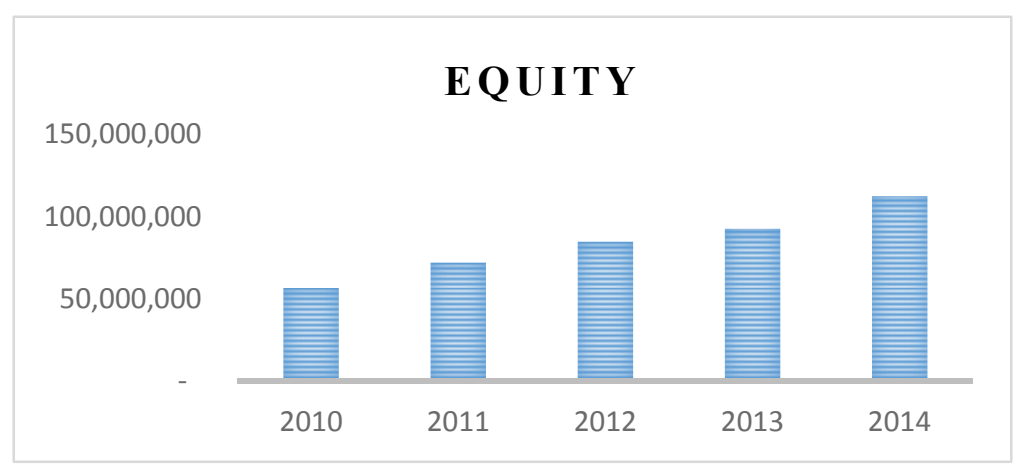

Figure 1. Equity value in the insurance industry

Based on Figure 1 above, it is known that the equity value of insurance companies continues to increase every year. This is related to the benefits and importance of insurance protection so that the insurance industry in Indonesia has a large market potential. This can be reflected in existing data where only $11.81 \%$ of Indonesia's population has access to insurance from a total of $88.19 \%(\mathrm{OJK}, 2016)$. Therefore, the insurance industry is projected to continue to grow. This growth is expected to contribute positively to the domestic economy. Failure to fulfill equity and obtain insufficient premiums can cause the company's operational failure. Until 2014 there were 39 insurance companies that were liquidated because one of them could not fulfill the required equity (OJK, 2014).

Sales revenue or premium rate has an important meaning for the insurance industry. The 
purpose of this sale is to get the maximum market share and measure the expected level of profit. The ups and downs of sales insurance companies can be seen from the intensity of consumer purchases.

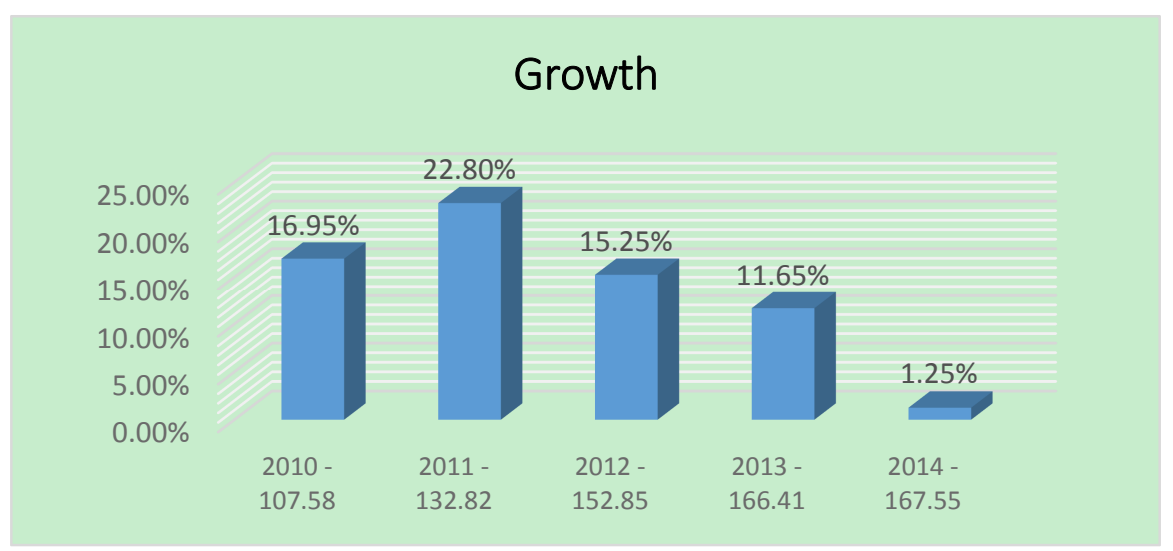

Figure 2. Insurance premium

In Figure 2, it can be seen that the premium rate of insurance companies shows a pattern that has decreased in percentage from 2011 to 2014. This is the opposite of the insurance value of insurance companies that increase every year. On the other hand, companies with high premiums will always need capital (in the insurance industry according to OJK, capital as a reference is the value of equity) which is getting bigger as well as vice versa companies in low sales growth, the need for capital is also minimal because it must follow the minimum capital standard provisions regulated by OJK.

The premium acquisition ratio can experience a sharp increase/decrease so that it can provide an indication of the lack of stability in the company's activities. This ratio gives an indication of the success rate of the insurance company in carrying out its business activities. This ratio can also be used as input to assess the readiness, capability and capacity of the company in facing premium growth that is too fast.

Printiani (2007) says that there is an influence between working capital and productivity on sales. In measuring working capital management in a company several indicators are used, namely asset structure as measured by Current Assets to Total Assets Ratio, working capital turnover is measured by Working Capital Turnover Ratio, liquidity is measured by Quick Ratio and working capital funding is measured by the debt structure. Asset structure is a balance or comparison in terms of both absolute and relative terms between current assets and fixed assets (Riyanto, 2011).

The main objective of investment policy is to implement a program plan that is made in order to achieve a positive return, with high stability of the assets available to be invested (Soemitra, 2009). The purpose of investment decisions is to get a large profit with risks that can be managed in the hope of optimizing sales. Investment decisions affect companies that show that there are a number of investments that will get a surplus if the company is able to make the right investment decisions. The surplus obtained will contribute to the cash inflow, then 
accumulated to increase the company's profit. Conversely, if the investment decision does not affect the company, it means that the company has a deficit of a number of investments made so that it will reduce equity and ultimately reduce the value of the company.

The larger the size of the company, the greater the asset structure of the company. Asset structure is a balance or comparison both in absolute terms and in the relative sense between current assets and fixed assets in determining the structure of wealth (Riyanto, 2001).

Ferdiyanto and Astuti (2014) say the growth of investment and assets can affect the level of equity of insurance companies, where if investment and assets grow, the company has sufficient reserve funds to pay claims if the insurance company goes bankrupt. On the other hand, if the insurance company cannot increase equity and assets, this will affect the insurance company's capital-based capital. Prospective investors who will invest their capital must pay attention to the return from the additional capital (optimizing its utilization rationally and professionally).

There are differences in the results of research conducted in previous studies (research gap). Research conducted by Hermuningsih (2012) and Muriira \& Bosire (2016) states that the relationship between investment and sales growth is not significant. In contrast to the research of Wiyadi et all (2017) and Oktaviani (2015), the investment return ratio has a positive effect on the growth of contribution income (premium income) in sharia life insurance companies in Indonesia. Furthermore, research conducted by Supriadi and Puspitasari (2012) found that between working capital and sales there was a significant influence. In contrast to the research conducted by Martini and Sugiharto (2004), it was found that effectiveness and working capital requirements did not affect sales and net income but had an effect on sales revenue.

Based on the description and research gap in previous studies, this research is also intended to further examine empirical findings on financial policy in terms of working capital, investment, assets and equity and its impact on the acquisition of insurance premiums. For this reason, researchers are interested in conducting research entitled: Factors that affect equity and the impact on the acquisition of premiums in general insurance companies in Indonesia in 2010 - 2014.

\section{Literature Review}

\subsection{Definition of Equity}

The term equity is called a net asset. Equity is defined as residual rights to the assets of the company after deducting all liabilities; this is to show that equity is not an obligation. Definitions are not different from FASB in SFAC No. 6. Because definitions are calculated on the basis of assets and liabilities, the value of equity also depends on how assets and liabilities are measured. Because of its important role, the regulation regarding the equity of the general insurance company is regulated by the Financial Services Authority regarding the minimum equity amount of POJK general insurance company No.67/POJK.05/2016 concerning business licensing and institutional insurance companies, sharia insurance companies, reinsurance companies and sharia reinsurance companies related to capital, namely, general insurance 
companies must have paid-up capital at the time of establishment of at least Rp.150,000,000,000.- (one hundred fifty billion rupiahs).

\subsection{Working Capital}

According to Jumingan (2011, p. 66) working capital is the amount of current assets. This amount is gross working capital. This definition is quantitative because it shows the amount of funds used for short-term operating purposes. The availability of working capital will depend on the type and level of liquidity of the elements of current assets such as cash, securities, accounts receivable and inventory. The notion of working capital according to Kasmir (2012: 250), namely the definition of working capital is the capital used to carry out operations of the company. Working capital is defined as investment invested in current assets or short-term assets, such as cash, banks, securities, accounts receivable, inventories and current assets.

\subsection{Investment}

The definition of investment in general is an activity or effort that can cause added value. Investment for an insurance company is a very important activity. This can be seen from the promise to pay later. In the promise contained a capability to develop funds (premiums) received from the community. For example in determining the premium level has calculated the interest element that will be paid to the insured or policy holder in the event of a claim. In the discussion of one of the functions of insurance is investment of funds (Dickson, 1991: 2). The types of investments allowed in general insurance have been regulated in accordance with KMK No. 224/1993 article 8, Types of Wealth Investments that are permitted in general insurance.

\subsection{Assets}

Assets are balance sheet elements that will form semantic information in the form of financial positions when connected with other elements, namely liabilities and equity. There are several sources of assets. Among them: FASC defines assets in the conceptual framework as follows (FSAC No.6 prg 25): "Assets are probable future economic benefits obtained from the past transaction or even". (An asset is a future economic benefit that is reasonably certain or obtained or controlled or controlled by an entity due to a transaction or past event). The types of assets that are permitted to follow KMK No. 224 of 1993 article 4.

\subsection{Insurance Premium}

Insurance premiums are premiums obtained from the insured, agent, broker or from other insurance companies and reinsurance companies. Insurance premiums originating from direct coverage (direct business) are called direct premiums. While premiums that come from indirect business (indirect business), namely those received from other insurance companies or reinsurance companies are called indirect premiums. The premium obtained is recognized as income based on accrual basis allocated evenly during the insurance period. Coinsurance income is recognized as a share (share) of premiums that will be received by the company (PSAK Insurance Loss No.28). 


\section{Research Methodology}

This research utilizes a panel data and ordinary least square model is employed. Before finalizing the final model, this study employs Haussmann specification test to determine the appropriate model to be used, such as fixed or random effect model. Independent variables are working capital, investment and assets. While the mediating variable is Equity and the dependent variable is Premium. The population referred to in this study is a general insurance company in Indonesia for the period 2014 - 2016. Determination of the sample in this study was done by purposive sampling that is selecting the research sample based on the target or target where in the sample selection is not random information obtained by using certain considerations or criteria (Sugiyono, 2012). From the description of sampling requirements, the research samples obtained as many as 24 companies with the following conditions: (1) General insurance company with equity up to IDR.175 Billion; (2) The Company has been in operation for more than 5 (five) years; (3) The Company submits annual reports regularly to the Financial Services Authority; (4) The company is not in the suspended status of the Financial Services Authority.

\section{Findings}

Descriptive statistics in this study are intended for the presentation of data descriptively so that readers easily understand the size of statistics to obtain a description of the characteristics of the spread of the value of each variable studied. Descriptive statistics used in terms of data presentation, central size, and size of dissemination. Size central include mean, median, and mode. The size of the spread includes the variance and standard deviation.

Table 1. Descriptive statistics

\begin{tabular}{llllll}
\hline & Premium & Equity & Working Capital & Investation & Asset \\
\hline Mean & $69,212.82$ & $82,087.19$ & $84,836.01$ & $88,742.33$ & $241,004.30$ \\
Median & $40,856.00$ & $81,592.00$ & $18,916.50$ & $74,449.50$ & $159,472.00$ \\
Maximum & $41,5141.00$ & $163,395.00$ & $151,6912.00$ & $272,380.00$ & $2,530,937.00$ \\
Minimum & $-41,916.00$ & $-55,182.00$ & $-258,853.00$ & $17,720.00$ & $51,194.00$ \\
Std Dev. & $82,493.09$ & $33,549.09$ & $222,056.20$ & $57,024.17$ & $281,180.90$ \\
\hline
\end{tabular}

Table 1 above shows that from 24 research data from 2010-2014 it is described that: Working Capital Variable of the lowest insurance company equal to $-258,853.00$ that is at As Sonwelis Airlines, while the highest working capital is 1,516,912.00 at Insurance Tugu Kresna Pratama. The mean or average working capital of general insurance companies in Indonesia in 2010-2014 amounted to 84.836.01. If the company has below average working capital then it is possible that the company will have difficulties in financing its operational activities. The standard deviation value is 222.056.20 means greater than the average value that exists, so it reflects that the working capital variable is not normally distributed. 
Investment Variable with the lowest value of 17,720.00 ie at KSK Indonesia Insurance while the highest value of 272,380.00 at Indrapura Insurance, Mean or average value of investment in general insurance company in Indonesia amounted to 88,742.33. The above average investment value means the company has a lot of funds to develop investment portopolio, whereas if below average there is not much choice for investment development. The standard deviation value is $57,024.17$ which means greater than the average value so it reflects that the distributed investment variable is not normal.

Asset variable at the lowest insurance company is equal to 51,194.00 that is at As Sonwelis Insurance Company, while the highest asset value is 2,530,937.00 at PT. Victoria Insurance. The mean or average value of assets of general insurance companies in Indonesia is 241,004.3. The above-average corporate asset value gives a better impact on company size and provides a reserve fund for debt repayment if no cash is available. The standard deviation value is $281,180.90$ which means greater than the average value that exists, it reflects that the distributed asset variable is not normal.

Variable Insurance Company's lowest equity is -55182.00 at Insurance Means of Protected Efforts while the highest equity value is $163,395.00$ at Indrapura Insurance. The mean or average value of the equity of general insurance companies in Indonesia is 82,087.19. Equity below the average will make the company's value low enough that it sometimes affects the bargaining position of the company with other entities. The default deviation value of 33.549.09 means less than the average value; it reflects that the equity variable is normally distributed.

Variable acquisition of premium insurance company is lowest -4,891.00 at Asuransi Berdikari while the highest premium is 415,141.00 at Eka Looyd Jaya Insurance. Mean or average value of premiums in general insurance companies in Indonesia amounted to 69.212.82. Companies that can book premiums above average means having a larger market share and can maximize the use of available resources. The standard deviation value of 82.493 .09 means greater than the average value, this reflects that the variable data of distributed premiums is not normal.

The regression result is presented below.

$$
Y 1=f(X 1, X 2, X 3) \rightarrow Y 1=c+\beta 1 X 1+\beta 2 X 2+\beta 3 X 3+\text { et }
$$




\section{Macrothink}

Table 2. Function of working capital, investment, and asset (fixed effect)

\begin{tabular}{lrlrc}
\hline \multicolumn{1}{c}{ Variable } & Coefficient & Std. Error & t-Statistic & Prob. \\
\hline MODALKERJA? & 0.013872 & 0.010328 & 1.343069 & 0.1825 \\
INVESTASI? & 0.676415 & 0.072751 & 9.297624 & 0.0000 \\
ASET? & -0.002745 & 0.008119 & -0.338052 & 0.7361 \\
C & 21545.23 & 6700.305 & 3.215560 & 0.0018 \\
Fixed Effects (Cross) & & & & \\
& & & \\
R-squared & 0.730955 & Mean dependent var & 82087.19 \\
Adjusted R-squared & 0.655738 & S.D. dependent var & 33549.09 \\
S.E. of regression & 19684.54 & Akaike info criterion & 22.80816 \\
Sum squared resid & $3.60 \mathrm{E}+10$ & Schwarz criterion & 23.43535 \\
Log likelihood & -1341.490 & Hannan-Quinn criter. & 23.06287 \\
F-statistic & 9.717964 & Durbin-Watson stat & 1.284453 \\
Prob(F-statistic) & 0.000000 & & \\
& & &
\end{tabular}

Equity $=21,545.23+0.013$ Working Capital +0.676 Investment -0.003 Asset +0.519 error

Constant 21,545.23 means if other variables are fixed then the Equity of 21,545.23. This equation indicates for each increase of one working capital unit then the equity will increase 0.013 units; every increase of one unit of Investment then Equity will increase 0.676 units; each increase of one Asset unit then the Equity will decrease -0.003 units at the level of 21,545.23.

The 2-substructure model is the Premium (Y2) as a function of Working Capital, Investment, Asset and Equity as follows.

$$
Y 2=f(X 1, X 2, X 3, Y 1) \rightarrow Y 2=c+\beta 1 X 1+\beta 2 X 2+\beta 3 X 3+\beta 4 Y 1+\text { et }
$$

Table 3. Function of working capital, investment, asset and equity (random effect)

\begin{tabular}{crrrr}
\hline Variable & Coefficient & Std. Error & t-Statistic & Prob. \\
EKUITAS? & 0.663050 & 0.276052 & 2.401905 & 0.0179 \\
MODALKERJA? & 0.032386 & 0.031041 & 1.043328 & 0.2990 \\
INVESTASI? & -0.058432 & 0.212599 & -0.274845 & 0.7839 \\
ASET? & -0.016656 & 0.024460 & -0.680955 & 0.4973 \\
C & 21237.06 & 21666.03 & 0.980201 & 0.3290 \\
Random Effects (Cross) & & & & \\
& & & & \\
R-squared & & & \\
Adjusted R-squared & 0.056134 & S.D. dependent var & 64464.25 \\
S.E. of regression & 62628.80 & Sum squared resid & $4.51 \mathrm{E}+11$ \\
F-statistic & 2.769313 & Durbin-Watson stat & 1.003409 \\
Prob(F-statistic) & 0.030578 & & \\
\hline
\end{tabular}

Premium $=21,237.06+0.032$ Working Capital -0.058 Investment -0.017 Asset +2.123 Equity 


\section{Macrothink Institute ${ }^{\mathrm{TM}}$}

Constant 21,237.06 means that if other variable is fixed then Premium equal to 21,237.06. This equation indicates for every increase of one working capital unit then Premium will rise 0.032 unit; every increase of one unit of Investment then Premium will fall-0.058 units; every increase of one Asset unit then Premium will drop - 0.017 units; every increase of one unit of Equity then Premium will increase 2,123 units at level 21,237.06. For clarity can be followed in the following picture.

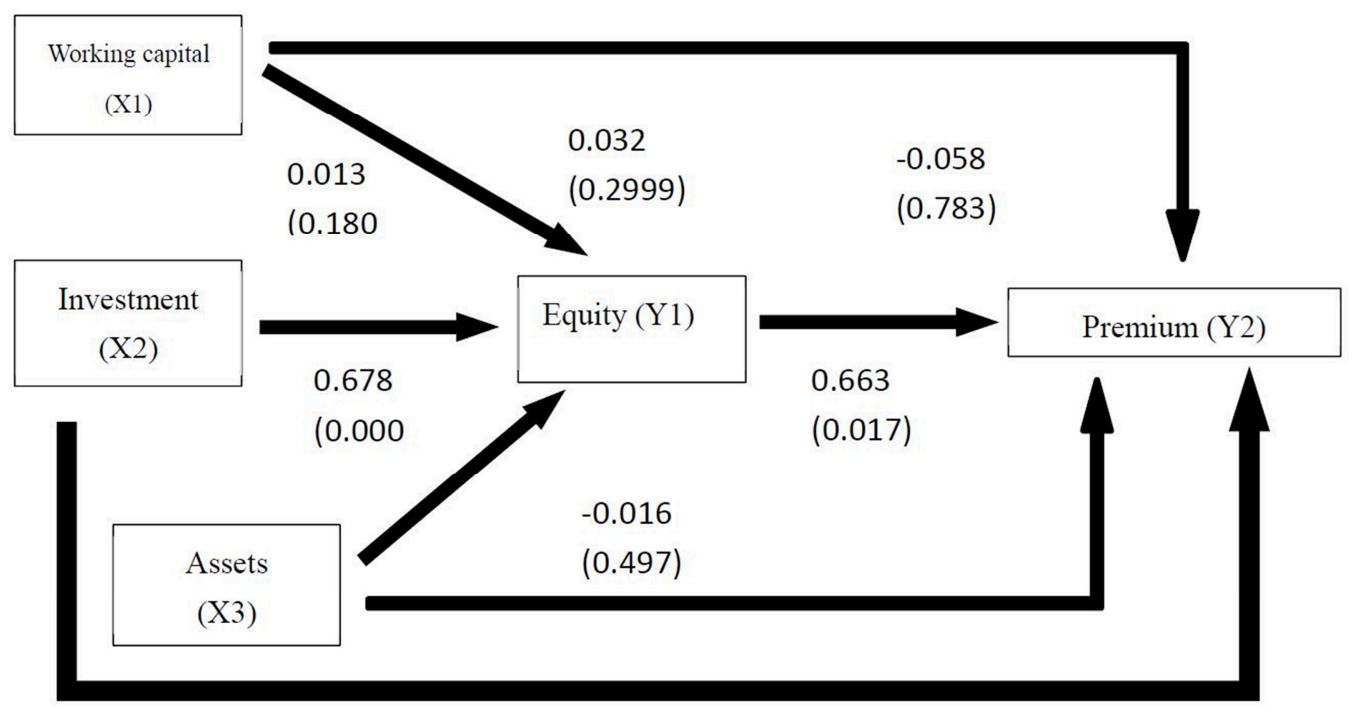

Figure 3.

\subsection{Direct Effect}

Effect of Working Capital on Equity. In the first hypothesis explained that Working Capital (X1) has a significant effect on Equity (Y1). Based on the calculation of significance level p-value 0.180 where p-value $(0.180>0.05)$ which means Working Capital (X1) has no significant effect on Equity (Y1). The results of this study indicate that working capital has no significant effect on corporate equity. The results of this study are in line with Warrad (2015)

The Effect of Investment on Equity. In the second hypothesis explained that Investment (X2) has a significant effect on Equity (Y1) in general insurance companies in Indonesia. Based on the calculation of p-value significance level of 0.000 , Level of significance shows p-value $0.000<0.05$ which means Investment significant effect between Investment (X2) to Equity (Y1). Thus there is a relationship between Investment and Equity. If investment improves, it indicates that the company's investment activity is improving, and if the improvement of this Investment is followed by the increase of interest income from the investment, then that means an increase in Equity. Thus we see a positive relationship Investment on Equity. The results reinforce the hypothesis of the direct effect of Investment on Equity. The results of this study are also in line with the research of Anakotta et al. (2010) and Hermuningsih (2012). 
The Influence of Assets on Equity. The third hypothesis in this study is Asset (X3) significantly influence the Equity (Y1) in general insurance companies in Indonesia. Based on the calculations performed shows that the $p$-value $>$ significance level $(\alpha)$, i.e., $0.738>0.05$. This illustrates that Assets have no significant effect on Equity. The results of this study indicate that assets have no effect on equity. Thus, asset hypothesis testing results have a positive effect on equity is not accepted or rejected. The results of this study contradict the hypothesis (assets have no effect on equity). The results of this study are in line with the research of Pouraghajan (2012), Ichwan and Widyawati (2015), Alvi and Ikram (2015), Goyal (2013).

Effect of Working Capital on Premiums. The fourth hypothesis in this study is Working Capital (X1) has a significant effect on Premium (Y2) in general insurance companies in Indonesia. The calculation result shows that $p$-value $>$ significance level $(\alpha)$, that is $0.299>0.05$. This illustrates that Working Capital has no significant effect on Premium. The results of this study indicate that working capital does not affect the premium. Thus, the results of hypothesis testing of working capital have positive effect to premium rejected. The results of this study are not in line with research Maheswara (2016), Suteja (2013), Motlicek \& Martinovicova (2014).

Effect of Investment on Premiums. In the fifth hypothesis explained that Investment (X2) has significant effect on Premium (Y2) in general insurance company in Indonesia. Based on the calculation shows that $p$-value of 0.783 , the result shows $p$-value $>0.05$ so that the result of influence that is not signifikan between Investment (X2) and Premium (Y2). The results of this study indicate that investment does not affect the acquisition or insurance premium income. Thus, the results of investment hypothesis testing have a positive effect on the premium rejected. Overall the results of this study support the hypothesis of a direct positive influence of investment on sales or premiums. It's just in this study found the opposite hypothesis, namely Investment to sales give a direct negative effect. The results of this study are in line with research by Ismayanti (2015), Setiawan (2012), Hudaya (2013), Muriira \& Bosire (2016).

The Influence of Assets to Premiums. In the sixth hypothesis explained that the Asset (X3) significantly affects the premium (Y2) in general insurance companies in Indonesia. Based on the calculation of path analysis shows that $\mathrm{p}$-value of 0.497 , the result shows $p$-value $>0,05$ which means Asset has no significant effect between Asset (X3) to Premium (Y2). Overall information about the performance of a good company Asset in a certain period of time is a positive information for investors to invest. Overall the results of this study support the hypothesis of a direct positive impact of assets on sales or premiums. It's just in this study found the hypothesis of assets to sales give a direct negative effect. The results of this study are not in line with research Pratiwi (2014), Noviliyana \& Irmadariyani (2012).

Effect of Equity on Premiums. In the seventh hypothesis explained that the Equity (Y1) significantly affects the premium (Y2) in general insurance companies in Indonesia. Based on the results of the calculation shows a significant level of significance of p-value of 0.017 , the results show p-value $0.017<0.05$. This means that Equity significantly affects Premium (Y2). The results of this study reinforce the hypothesis that equity directly affects positively to premiums. The results of this study are in line with the research of Saad (2014), Njagi (2017), 
Mwangi and Iraya (2014), Paglia \& Harjoto (2014), Saad (2014), Gonga \& Sasaka (2017).

\subsection{Indirect Effect}

Effect of Working Capital on Premiums through Equity. Fourth hypothesis in this research is Working Capital (X1) have an effect on significant to Premium (Y2) through variable equity at general insurance company in Indonesia. The result of the calculation shows that the direct effect of working capital variable to the premium is 0.0010 and the indirect influence influenced by the equity variable is 0.009 . This result shows that to measure the increase of premium gain through equity variable is better done by considering equity variable. The results of this study indicate that working capital affects premiums through equity variables. Thus, the result of hypothesis testing of working capital has positive effect on the premium through equity is accepted. The results of this study are in line with Maheswara (2016), Suteja (2013), Motlicek dan Martinovicova (2014).

The effect of investment on premiums through equity. The results showed that investment had a significant positive effect on premium through equity. This is seen from the second hypothesis testing that states that investment has a significant positive effect on equity and seen from the seventh hypothesis that states equity has a significant positive effect on premiums. Furthermore, the direct influence of investment variable to premium is 0.0033 and the indirect influence influenced by the equity variable is 0.449 . This result shows that to measure the increase of premium gain through equity variable is better done by using equity variable. So investment has a significant positive effect on equity, meaning that high investment equity is also high. In this case, if the investment is high then it can influence the management decision in increasing equity. Investment and asset growth can affect the level of equity of insurance companies, where if investments and assets grow, the company has enough reserve funds to pay claims if the insurer goes bankrupt. The purpose of making an investment decision is to earn a large profit with risk that can be managed in the hope it can optimize sales. So Equity mediates investment against premiums. So investment has a significant positive effect on premium through equity as intervening variable.

Effect of Assets on premiums through Equity. The result of research indicates that the asset influences the premium through equity. Assets have an effect on equity, meaning that the slightest increase in assets acquired by the company will affect the equity. The result of calculating the direct effect of asset to premium is 0.0003 and the indirect influence influenced by the equity variable is -0.001 . This result shows that to measure the increase of premium gain through the equity variable is better done by considering the equity variable, due to the acquisition of premium through the variable of equity of acquisition better than with the direct influence of working capital to premium. On the other hand, if the insurer cannot increase equity and assets, this will affect the risk-based capital of the insurance company. So equity mediates the effect of assets on premiums. So the asset affects the premium through equity as an intervening variable.

\section{Conclusion}

This study aims to examine the factors that affect the equity and its impact on the acquisition 
of premiums in general insurance companies in Indonesia in 2010 - 2014. Based on the results of research, it can be concluded that (1) Working Capital has no effect on Equity; (2) Investment has a significant positive effect on equity; (3) Assets have no effect on Equity; (4) Working Capital has no effect on Premium; (5) Investment has no effect on Premium; (6) Assets have no effect on Premium; (7) Equity has a significant positive effect on Premium; (8) Variable of Working Capital, Investment and Asset give indirect influence to premium through variable Equity.

\section{References}

Alvi, M., \& Ikram, M. (2015). Impact of total assets and net income on return on equity of small medium enterprises of pakistan. MPRA Paper No. 64876.

Anakotta, F. (2010). Factors affecting equity profitability (Case study of Maluku Tengah Regency). Cita Ekonomika, 4(2).

Gonga, M. A., \& Sasaka, P. S. (2017). Determinants of financial performance of insurance firms: a survey of selected insurance firms in Naerobi County. The Journal of Management, $4(8), 123-143$.

Goyal, A. M. (2013). Impact of capital structure on performance of listed public sector banks in India. International Journal of Business and Management Invention, 2(10).

Hermuningsih, S. (2012). Factors affecting disclosure and its impact on cost of equity capital. Business and Management Review, 13(1).

Hudaya, D. R. (2013). The effect of investment in fixed assets and maintenance costs on operating income. E-journal accounting Siliwangi University, 2(1).

Ichwan, F. Y., \& Widyawati, D. (2015). Influence of firm size, asset structure and profitability to capital structure. Journal of Accounting Science and Research, 4(6).

Indonesian Accounting Association. (2002). Statement of Financial Accounting Standards (PSAK) No. 49. Salemba Empat, Jakarta.

Ismayanti, W. (2015). The influence of government investment and economic growth on local revenue (Case study in Tasikmalaya city administration). E-journal Accounting, 4(2).

Jumingan. (2011). Financial Statement Analysis. Jakarta: Earth Literacy.

Maheswara, A. A. N. G. (2016). Analysis of factors that influence the income of SMEs trade sector in the city of Denpasar. E-Journal of economics and business of Udayana University, $5(12)$.

Motlicek, Z., \& Martinovičová, D. (2014). Impact of working capital management on sales of enterprises focusing on the manufacture of machinery and equipment in the Czech Republic. Acta Univesitatis Agriculture et Silviculture Mendeliane Brunensis, 62(4). https://doi.org/10.11118/actaun201462040677

Muriira, P. K., \& Bosire, N. (2016). Assessment of factors influencing revenue growth of 
insurance companies in Nakuru Town, Kenya. International Journal of Economics, Commerce and Management, 4(4).

Mwangi, M., \& Iraya, C. (2014). Determinants of financial performance of general insurance underwriters in Kenya. International Journal of Business and Social Science, 5(13).

Njagi, I. K. (2017). Equity financing and financial performance of small and medium enterprises in Embu Town, Kenya. International Academic Journal of Economic and Finance, 2 .

Noviliyana, R., \& Irmadariyani, R. (2012). Analysis of the effect of profitability and stock prices on the volume of stock sales of empirical studies on food and beverage companies listed on the Indonesia Stock Exchange. Scientific art of students - University of Jember.

Paglia, J., \& Harjoto, M. A. (2014). The effects of private equity and venture capital on sales and employment growth in small and medium sized businesses. Journal of Banking and Finance, 47, 177-197. https://doi.org/10.1016/j.jbankfin.2014.06.023

Pouraghajan, A. (2012). The relationship between capital structure and firm performance evaluation measures: Evidence from the Tehran Stock Exchange. International Journal of Business and Commerce, 1(9).

Pratiwi, K. G. (2014). The effect of asset structure on sales growth and its impact on operating profit. E-journal Accounting, 3(1).

Printiani, I. (2007). Influence of working capital and productivity against sales volume (Case study at Galunggung Raya Tasikmalaya).

Riyanto, B. (2011). Fundamentals of Company Spending. BPFE, Yogyakarta.

Saad, R. M. (2014). Effects equity and debt financing on SME performance in Malaysia. International Journal of Marketing Studies, 1(2).

Setiawan, J. (2012). Analysis of several factors that affect the income level of small leather shoe industry in Magetan Regency. Journal of Akmenbis, 1(1).

Soemitra, A. (2009). Banks and Islamic Financial Institutions. Jakarta: Kencana Pranada Media Group.

Sugiyono. (2012). Educational Research Methods (Quantitative Approach, Qualitative, and $R$ $\& D)$. Bandung: Alfabeta.

Suteja, A. R. (2013). The influence of working capital and labor productivity on the volume of work. E-Journal Accounting, 2(2).

Warrad, L. (2015). The impact of turnover ratios on Jordanian services sectors' performance. Journal of Modern Accounting and Auditing, 11(2). 


\section{Copyrights}

Copyright for this article is retained by the author(s), with first publication rights granted to the journal.

This is an open-access article distributed under the terms and conditions of the Creative Commons Attribution license (http://creativecommons.org/licenses/by/4.0/). 